vened three-judge court is not void for want of jurisdistion, ${ }^{72}$ as is the decree of a single judge when three are required. However, the Supreme Court will dismiss an appeal from such a court as soon as the defect is discovered. This necessitates the delay and expense of a second appeal, ${ }^{73}$ this time to the court of appeals. But even that may not be possible. By the time the Supreme Court has dismissed the first appeal, the time for appealing to the court of appeals will probably have expired. ${ }^{74}$ This can be remedied only by securing an order from the Supreme Court directing the district court to enter a new decree from which a timely appeal can be taken. While in most cases the Supreme Court has been willing to issue such an order, in some cases it has refused to do so, leaving the appellant remediless. ${ }^{75}$ The only safe course would seem to be to file two appeals, one to the Supreme Court and one to the court of appeals, whenever there is doubt as to whether or not a three-judge court has been properly convened.

It is submitted that retention of the three-judge procedure is unjustified. The needs for which it was designed are largely a thing of the past, and its remaining functions have been taken over by other procedures. Far from furnishing speedy justice in cases of "vast public moment," the three-judge procedure has proven in operation to be a heavy burden on the courts and a source of procedural pitfalls for litigants. The Three-Judge Acts survive as little more than an expression by Congress of a lack of confidence in the judiciary.

72 Healy v. Ratta, supra note 71.

${ }^{73}$ The delay can be considerable. In Healy v. Ratta, supra note 71, for example, two years were lost between the original three-judge decree granting an injunction and the final decision in the Supreme Court, which reversed the same decree and dissolved the injunction. In the meantime, af ter theSupreme Court had dismissed a direct appeal on the ground that the threejudge court had been unnecessarily convened, the court of appeals had taken the appeal on the merits, 67 F.2d 554 (1st Cir. 1933), and the case had reached the Supreme Court by certiorari.

${ }^{74}$ An appeal to the court of appeals must be taken within thirty days from the entry of judgment in the district court. FED. R. Crv. P. 73 (a).

${ }^{75}$ E.g., Smith v. Wilson, 273 U.S. 388 (1927); Moore v. Fidelity \& Deposit Co., 272 U.S. 317 (1926). In the Smith case the plaintiff then applied to the Supreme Court for mandamus to compel the circuit court of appeals to accept his appeal even though it was too late. The Supreme Court denied the writ. Ex parte Smith, 274 U.S. 723 (1927). The case is discussed in Sloss, supra note 69 , at 99.

\title{
FEDERAL HABEAS CORPUS AND INVOLUNTARY CONFESSIONS
}

When a defendant in a state criminal prosecution challenges the admission of his confession, alleging it was coerced, ${ }^{1}$ states following the orthodox proce-

1 The United States Supreme Court first used the due process clause of the fourteenth amendment to upset a state conviction based on an involuntary confession in Brown v. Miss'ssippi, 297 U.S. 278 (1936). That conviction rested solely upon a confession obtained through physical violence. In Malinski v. New York, 325 U.S. 401 (1945), the Court held that the admission into evidence of a coerced confession automatically voids a conviction under the due process clause, no matter how persuasive the remaining evidence of guilt. This rule of "automatic reversal" was coupled with a progressively broadened concept of what constitutes involuntariness. E.g., Haley v. Ohio, 332 U.S. 596 (1948) (tender age); Watts v. Indiana, 338 
dure $^{2}$ require the trial judge to determine specifically that the confession was voluntary before admitting it as evidence. However, under "New York" procedure, the trial judge need only determine that a "fair question of fact" exists as to whether the confession was coerced before submitting it to the jury. The jury is instructed to determine the coercion issue first, and to disregard the confession if they find it was involuntary, but their finding on coercion is buried in a general verdict. ${ }^{3}$ The United States Supreme Court in Stein v. New York $k^{4}$ upheld the constitutionality of this procedure holding that the due process clause of the fourteenth amendment was not violated if the jury either found the confession voluntary and utilized it or found it involuntary and disregarded it. ${ }^{5}$ The Court refused to presume that the jury would fail to resolve the coercion issue or that it might utilize the confession after finding it was coerced. ${ }^{6}$ The Court further indicated that the allocation of function between judge and jury is within the discretion of the states and that its review of state prosecutions would not be influenced by the particular allocation adopted. ${ }^{7}$

However, two subsequent Court of Appeals decisions, Cranor v. Gonzales ${ }^{8}$ and United States ex rel. Rogers v. Richmond, ${ }^{9}$ seem to hold that the scope of review by federal district courts in habeas corpus proceedings ${ }^{10}$ does depend upon the

U.S. 49 (1949) (relay questioning); Leyra v. Denno, 347 U.S. 556 (1954) (psychiatric inducement); Fikes v. Alabama, 352 U.S. 191 (1957) (incommunicado detention of prisoner with subnormal intelligence).

2 The descriptions of the orthodox and "New York" procedures in the text represent brief general outlines. For more elaborate treatment, see Meltzer, Involuntary Confessions: The Allocation of Responsibility Between Judge and Jury, 21 U. CEr. I. REv. 317, 319-24 (1954); Maguire, Preliminary Qutestions of Fact in Determining Admissibility of Evidence, 40 HARv. L. REv. 392, 413-24 (1927); 3 WiGMoRe, EvIDENCE, $\$ 861$, and 9 id., \$\$ 2550-51 (3d ed. 1940). Wigmore terms the departure from orthodox procedure as "heresy" prompted by a confusion of admissibility and credibility, the former being the exclusive province of the judge and the latter of the jury. See also Annot., 170 A.L.R. 567 (1947).

${ }^{3}$ In most jurisdictions statutory or constitutional changes would be necessary to permit verdicts in criminal cases. See generally 23 C.J.S., Criminal Law $\$ 1399$ (1955).

4346 U.S. 156 (1953).

$5 \mathrm{Id}$. at $193-4$.

${ }^{6} I d$. at 170. Cf. Meltzer, supra note 3; Gorfinkel, Fourteenth Amendment and State Criminal Proceedings- "Ordered Liberty" or "Just Deserts," 41 CALIF. L. REv. 118 (1953); Note, 52 MICH. L. Rev. 421 (1954).

${ }^{7}$ Id. at 179. See also Thomas v. Arizona, 356 U.S. 390, 393 (1958); Minneapolis \& St. Louis R.R. v. Bombolis, 241 U.S. 211 (1916); Walker v. Sauvinet, 92 U.S. 90 (1875).

8226 F.2d 83 (9th Cir. 1955), affirming Giron v. Cranor, 116 F. Supp. 92 (E.D. Wash. 1953), cert. denied, 350 U.S. 935 (1956).

${ }^{9} 271$ F.2d 364 (2d Cir. 1959), cert. granted, 361 U.S. 959 (1960).

${ }^{10}$ Federal Habeas Corpus Act, 28 U.S.C. $\$ \S 2241-55$ (1958). The statutory writ is a collateral attack upon the jurisdiction of the convicting court, which jurisdiction is lost if the Constitution or a federal law is violated. Johnson v. Zerbst, 304 U.S. 458, 466-68 (1938). See Holtzoff, Collateral Revieve of Convictions in Federal Courts, 25 B.U.L. REv. 26 (1945). 
state procedure used. To the extent that federal review of the factual issues ${ }^{11}$ involved in the coercion question may vary according to the state trial procedure the vitality of the Stein decision seems impaired.

I

In Cranor v. Gonzales, ${ }^{12}$ the defendant had been convicted of murder in a Washington state court which had employed the "New York" procedure. After exhausting his appeal remedies, he applied for a federal writ of habeas corpus, claiming that his coerced confession had been improperly admitted at trial. The federal district judge ordered a hearing, and then, after an examination of the same witnesses who had appeared at the trial, made specific findings on the facts allegedly constituting coercion..$^{13}$ On the basis of these findings he held that the confession was involuntary and granted the writ of habeas corpus. The Court of Appeals for the Ninth Circuit affirmed, holding that the district court had discretion to hold a hearing and determine factual issues for itself. ${ }^{14}$ The Court of Appeals also had to meet the argument of the state that even if the district court could find the confession coerced, it was not permitted to grant the writ because under the Stein rationale it should be assumed that the jury had disregarded the confession and convicted on the basis of other evidence. The Court of Appeals answered, first, that the fact finding capacity of the federal district court on habeas corpus was broader than that of the Supreme Court on certiorari because the district court could receive evidence and hear witnesses whereas the Supreme Court could not implement the record before it. ${ }^{15}$ Hence, the district court was capable of deciding the factual issues of coercion rather than merely considering hypothetical alternatives of jury action on this issue. ${ }^{16}$ Second, since the confession was now found to be coerced, it would be improper to make the defendant prove that the jury had not disregarded his coerced confession in reaching its verdict. To do so, the court reasoned, would be to impose an impossible task upon a defendant seeking vindication of his

11 If the factual circumstances (in the sense of historical events) surrounding the confession are undisputed, the federal judiciary, including the United States Supreme Court on certiorari from a state court, will always exercise independent judgement on the legal inference to be drawn from those facts. See Payne v. Arkansas, 356 U.S. 560 (1958); Spano v. New York, 360 U.S. 315 (1959); Brown v. Allen, 344 U.S. 443 (1953). This is not to suggest that the demarcation between questions of law and questions of fact is always clear. See, e.g., Leyra v. Denno, 347 U.S. 556 (1954).

12226 F.2d 83.

${ }^{23}$ Both in the state trial and at the federal habeas corpus hearing, Gonzales repudiated his confession and testified that he confessed only after being beaten and kicked by the police and threatened with further violence. The policemen he accused denied his charges in both courts. The district judge found "that, basically Gonzales' story is a true story." 116 F. Supp. at 95 .

14226 F.2d at 92 . ${ }^{15} 226 \mathrm{~F} .2 \mathrm{~d}$ at 91.

${ }^{16}$ Ibid. See also Note, 8 Stan. I. Rev. 451 (1956). 
constitutional rights. The presumption of jury regularity was therefore rejected. ${ }^{17}$

The defendant in United States ex rel. Rogers v. Richmond ${ }^{18}$ had been convicted of murder in a Connecticut state court which had employed the orthodox procedure to determine that his two confessions, were voluntary and admissable. ${ }^{19}$ After exhausting his appeal remedies the defendant sought federal habeas corpus again claiming that his confessions were involuntary and should not have been admitted as evidence. The district court ordered a hearing and without examining the portion of the state record bearing on the voluntariness of the confessions, independently resolved the pertinent facts contrary to the trial court. ${ }^{20}$ On the basis of the redetermined facts the district court found that the first confession was involuntary and granted the writ. The Court of Appeals for the Second Circuit reversed, holding that the district judge should make his findings solely upon the basis of the facts as found in the trial record unless he found a "vital flaw" or unusual circumstances in the record. ${ }^{21}$ Cranor v. Gon$z a l e e^{22}$ was distinguished as dealing with "New York" procedure where the record contained no specific finding of facts on the coercion issue..$^{23}$ The Supreme Court denied certioriari, stating per curiam,

We read the opinion of the Court of Appeals as holding that while the District Judge may, unless he finds a vital flaw in the State Court proceedings, accept the determinations in such proceedings, he need not deem such determination binding, and may take testimony. ${ }^{24}$

On remand, the same district judge construed the two opinions above to mean that although he had the power to hold a hearing and to take testimony at his discretion, ${ }^{25}$ he was nevertheless bound by the findings of fact made by the trial judge in the state court if such a hearing developed no evidence different

${ }^{17} 226$ F.2d at 90 . In Stein v. New York, submission of the coercion issue to the jury was characterized as a "practice on the whole assumed to be of advantage to the defense and an additional protection to the accused." 346 U.S. at 189. WIGMORE, EVIDENCE $\$ 861$ (2d ed. 1940), notes that this "heresy" has made rapid strides in recent years. Cf. Meltzer, supra note 2, at 338-39.

18271 F.2d 364.

${ }^{19}$ State v. Rogers, 143 Conn. 167, 120 A2d 409 (1956), cert. denied, 351 U.S. 952 (1956). At trial the state judge merely ruled the confessions were voluntary. Following Rogers' conviction the trial judge made specific findings of the facts on which his ruling was based to permit an appeal to be perfected.

${ }^{20}$ United States ex. rel. Rogers v. Cummings, 154 F. Supp. 636 (D. Conn. 1956). The discrepancy between the findings of the state trial court and the district court was first noted on remand in United States ex. rel. Rogers v. Richmond, 178 F. Supp. 69, 70 (D. Conn. 1958). The district judge found that Rogers did make a request to call his counsel. The trial judge had found otherwise. The only evidence on this point in either court was the testimony of Rogers, contradicted by the testimony of the police.

${ }^{21}$ United States ex. rel. Rogers v. Richmond, 252 F.2d 807, 811 (2d Cir. 1958).

2226 F.2d 83.

${ }^{23} 252$ F. $2 d$ at 810.

24357 U.S. 220 (1958).

25 The district judge noted that "circumstances" must justify the exercise of this discretion, but did not indicate what those circumstances were. 178 F. Supp. 69, 72 (D. Conn. 1958). 
from that presented in the state trial. ${ }^{26} \mathrm{He}$ then found that the evidence before him was essentially similar to that developed before the state trial judge and denied the writ. The Court of Appeals affirmed the denial and approved the standards he had announced. ${ }^{27}$

\section{III}

The holdings of Cranor v. Gonzales ${ }^{28}$ and United States ex rel. Rogers v. Richmond $d^{29}$ on the scope of federal habeas corpus in the coerced confession cases may be summarized as follows: (1) At the initial stage of the federal court's determination of whether to hold a hearing upon application for writ, both cases affirm the power of the court to hold a hearing at its discretion even though new evidence might not be prospectively forthcoming. ${ }^{30}$ (2) At the stage of making findings of fact pertinent to the voluntariness or involuntariness of the confession, the cases differ according to the procedure followed in the state trial. Under the Rogers rule, where the trial followed orthodox procedure, the federal judge is bound by the specific findings of fact made by the state trial judge unless new evidence is presented at the habeas corpus hearing. Under the Cranor rule where the trial followed "New York" procedure and there is no specific finding on the issue of voluntariness in the state record, the federal judge is free to make independent findings of fact on this issue even though no new evidence appears at the habeas corpus hearing. (3) At the stage of granting the writ, both cases permit the writ to be granted if the federal court finds that the confession was coerced. In the Cranor case, this involved rejection of the presumption that the jury also found the confession coerced and thereupon disregarded it. Under the Rogers situation, since orthodox procedure involves instructing the jury to utilize the confession, the writ automatically follows, if the federal judge is able to find the confession coerced within his imited scope of review.

${ }^{26} \mathrm{Id}$. at 73 .

27 In the view of the Court of Appeals, the district judge did not include the finding that the confessions were voluntary as one of those facts on which he was bound. 271 F.2d at 367 . However, the district court opinion is extremely ambiguous on this point. Compare: "Unless, on consideration of the full record such grounds are found, this court must accept the findings of historical fact in reaching its determination on the constitutional issues. This court is bound by the findings of the state trial court that no request for counsel was made, and that the confessions were voluntary. ..." $178 \mathrm{~F}$. Supp. at 71, with "[W] hile the District Judge may take additional testimony not considered by the state trial court on constitutional issues, such as the lack of due process by the use of coerced confessions, and make independent determination of the facts, such as the voluntary character of confessions, and must independently determine whether the conviction may constitutionally stand, he may not substitute his judgement on factual issues fairly tried (i.e. where no vital flaw exists) before the state court, on similar evidence." $I d$. at 72 .

${ }^{28} 226$ F.2d 83.

${ }^{29} 271$ F.2d 364.

${ }^{30}$ This discretionary authority to hold a hearing is expressly approved in the per curiam opinion in Rogers v. Richmond, 357 U.S. 220, and implicit in Cranor v. Gonzales, 226 F.2d 83. See also Brown v. Allen, 334 U.S. 443, 463-4 (1953). Cf. note 25 supra. 
It may be seen that the essential difference between the two rules is the extent of the federal judge's ability to make his own findings of fact pertaining to voluntariness. The basis for this difference is that there is no specific finding by a state court as to voluntariness under "New York" procedure. Stein v. New York $^{31}$ was criticized for appearing to do away with the doctrine of constitutional fact-under which a criminal defendant is entitled to a specific finding as to the facts upon which his constitutional rights depend" ${ }^{32}$-in "New York" procedure cases. ${ }^{33}$ If Cranor v. Gonzales ${ }^{34}$ erects the proper rule governing federal habeas corpus review of "New York" procedure, application of the constitutional fact doctrine seems merely deferred from appellate review by the Supreme Court to habeas corpus review by the federal district court.

Perhaps more important, however, is the impact which Cranor v. Gonzales ${ }^{35}$ and United States ex rel. Rogers v. Richmond ${ }^{36}$ together may have upon state trial procedures. If federal district courts are bound by state determinations when the local procedure was orthodox, whereas use of "New York" procedure permits a far more searching review by the federal court, then federal law appears to discriminate in favor of orthodox procedure. Through their use of habeas corpus, federal courts may "coerce" state courts into adoption of orthodox procedure in order to avoid federal harassment about coerced confessions. ${ }^{37}$ Since Stein v. New York" upheld the constitutionality of "New York" procedure, it may be anomalous for the states which have followed "New York" procedure to find that their reliance upon the Stein opinion may have been misplaced.

It seems unwise to extend either the Cranor or the Rogers rules to cover all forms of state procedure merely to achieve uniformity of federal review power. Application of the Rogers rule of limited review to cases involving "New York" procedure imposes an unenviable burden upon the defendant who can prove

31346 U.S. 156.

${ }^{32}$ See St. Joseph Stock Yards Co. v. United States, 298 U.S. 38, especially the concurring opinions of Brandeis, J., id. at 73, 77, 84, and of Stone and Cardozo, JJ., id. at 93 (1936); $\mathrm{Ng}$ Fung Ho v. White, 259 U.S. 276, 282-85 (1922); Meltzer, supra note 2, at 251. Hart, The Power of Congress to Limit the Jurisdiction of Federal Courts, 66 HARv. L. REv. 1362, 1376-83 (1953), indicates that the doctrine has faded in civil cases, but a caveat is expressed as to its force in criminal law. Cf. Holtzoff, supra note 10, at 32.
${ }^{33}$ Meltzer, supra note 2, at 251.
${ }^{35}$ Ibid.
${ }^{34} 226$ F.2d 83.
${ }^{36} 271$ F.2d 364 .

${ }^{37}$ Recourse to a third procedure for resolving the coercion issue, the "Massachusetts" or "humane" rule, wherein the trial judge specifically decides the voluntariness issue as under orthodox procedure but nevertheless permits the jury to review his findings, might preserve immunity from federal review of factual questions for states desiring a jury decision on all questions of fact. However, doubt has been cast on the thoroughness of the judge's findings under this procedure in view of the jury review. Meltzer, supra note 2, at 329. Federal review might be guided accordingly. Cf. Newman v. State, 148 Tex. Crim. 645, 651-52, 187 S.W.2d $559-63$ (1945).

38346 U.S. 156. 
that his confession was coerced, but is necessarily unable to show that the jury did not disregard the confession in convicting him. Application of the Cranor doctrine of unlimited review to cases involving the orthodox procedure seems to unduly extend the circumscribed power of review by federal courts over state criminal prosecutions. The disharmony between Stein and the habeas corpus cases can of course be resolved by overruling the Stein opinion. The Supreme Court recently granted certiorari to review the last Court of Appeals decision in United States ex rel. Rogers v. Richmond..$^{39} \mathrm{It}$ is hoped the Court will use this case as an opportunity to clear up the many doubts created by the Stein case as to the vitality of the rule of constitutional fact as well as the scope of federal habeas corpus review over state criminal procedures.

${ }^{30} 361$ U.S. 959 (1960). 